\title{
36. SUBMARINE SLOPE STABILITY ANALYSIS ON THE DETROIT SEAMOUNT, SITE 883
}

\author{
John A. Roberts, ${ }^{2}$ Anne K. Rutledge, ${ }^{3}$ and Aarno T. Kotilainen ${ }^{4}$
}

\begin{abstract}
Diatom- and clay-rich sediments sampled from the Detroit Seamount were tested to determine the parameters required for slope stability analysis. Consolidation tests performed show that the sediments are apparently overconsolidated in the upper $24 \mathrm{~m}$ of the section and become normally consolidated at greater depths. Triaxial testing shows that the major sediment types (clays and diatom oozes) cannot be distinguished on the basis of normalized strength parameters. The results of a slope stability analysis using the infinite slope theory indicate that the sediments are unstable when subjected to earthquake ground accelerations in excess of $7 \%$ to $8 \%$ of gravity on the flanks and $10 \%$ to $11 \%$ on the top of the seamount. Examination of stress path plots show that most of the samples tested exhibit a nondisintegrative nature, that would be expected to produce slump blocks or slides.
\end{abstract}

\section{INTRODUCTION}

The study of the stability of submarine slopes has increased in interest to marine geologists over the past $20 \mathrm{yr}$, as the extent of downslope mass movement processes has become clear. Very large slope failures have been documented from around the world (e.g., Lewis, 1971; Embley, 1976; Masson et al., 1992). Slope failure can be caused by a number of factors in the deep sea; some of the more popular hypotheses include earthquake loading (perhaps the most likely), sea-level rise and fall, and gas hydrate destabilization.

The sediments cored at Site 883, located on the Detroit Seamount in the northwest Pacific, have been divided into six lithologic units (see Shipboard Scientific Party, 1993). The sediments of Unit I were tested in this study using 14 whole-round samples that were taken from Holes $883 \mathrm{~A}$ and $883 \mathrm{~B}$ (to a maximum depth of $45 \mathrm{mbsf}$ ) for geotechnical testing. These sediments are clays and diatom oozes with minor lithologies of spiculite, carbonate, and some ash layers.

The purpose of this study is to assess the composition, in situ strength, and physical properties of the sediments on top of the Detroit Seamount and to relate these to (1) the sediment stability, (2) the seismicity of the region, and (3) the sediment composition. The effect of biogenic silica content on the geotechnical properties of a sediment has been considered by other workers, such as Pittenger et al. (1989), who concluded that siliceous layers on the Vøring Plateau may represent zones of weakness in sedimentary sections. Bryant and Rack (1990) concentrated on consolidation characteristics of siliceous sediments from the Weddell Sea and found that all the surficial diatomaceous sediments they sampled were overconsolidated. They attributed this to diatom tests forming a strong microfabric (with calcareous and clay particles) and thus attaining a high permeability which would permit the rapid drainage of pore waters and an increased sediment strength.

\section{METHODS}

In addition to the methods used to determine index properties and vane shear strength (Shipboard Scientific Party, 1993), the following procedures have been employed.

\footnotetext{
${ }^{1}$ Rea, D.K., Basov, I.A., Scholl, D.W., and Allan, J.F. (Eds.), 1995. Proc. ODP, Sci. Results, 145: College Station, TX (Ocean Drilling Program).

${ }^{2}$ Marine Geoscience Research Group, Department of Earth Sciences, University of Wales, P.O. Box 914, Cardiff CF1 3YE, United Kingdom.

${ }^{3}$ Department of Oceanography, Texas A\&M University, College Station, TX 77843, U.S.A.

A. bridge CB2 3EQ, United Kingdom.
}

\section{Consolidation Tests}

One-dimensional consolidation tests were performed using Soil Testing Inc. oedometers at Texas A\&M University. The samples (cut to a size of $6.35 \mathrm{~cm}$ diameter by $2.54 \mathrm{~cm}$ high) were laterally constrained while being incrementally loaded up to $800 \mathrm{kPa}$ and then rebounded to $50 \mathrm{kPa}$, while changes in sample height were measured using linear strain conversion transducers (LSCTs). The maximum load used ( 800 $\mathrm{kPa}$ ) is rather low, because of restrictions during the testing program. Relationships of vertical displacement and time were obtained and analyzed using the procedure outlined in BS 1377 (1975), and Head (1982) to yield values for $c_{v}$ (coefficient of consolidation $\left.\left[\mathrm{cm}^{2} \mathrm{~s}^{-1}\right]\right), m_{v}$ (coefficient of volume compressibility $\left[\mathrm{m}_{2} \mathrm{MN}^{-1}\right]$ ) and $k$ (permeability $\left.\left[\mathrm{ms}^{-1}\right]\right)$. The void ratio at the end of each loading stage was calculated and plotted on a graph vs. log effective stress. The Casagrande (1936) analysis was performed on these plots, and the overconsolidation ratio (OCR) was calculated $\left(\mathrm{OCR}=\sigma_{v m}^{\prime} \sigma_{v}^{\prime}\right.$, the ratio of the maximum past overburden pressure and the present overburden). An OCR of one indicates that the sample is normally consolidated, values less than one and greater than one indicate under and overconsolidation, respectively. The disadvantages of the Casagrande method have been reported by both the Marine Geotechnical Consortium (1985) and Bryant and Rack (1990), and will not be discussed here.

\section{Triaxial Tests}

The sediment strength was determined using triaxial testing methods (isotropic consolidation and undrained shear, or CIU) following the normalized strength parameter (NSP) approach devised by Ladd and Foott (1974) and Ladd et al. (1977). This methodology has also been used by researchers in the Gulf of Alaska and off the coast of California (e.g., Lee and Edwards, 1986; Hampton, 1989). The method uses elevated consolidation pressures $\left(\sigma_{c}^{\prime}\right.$ : consolidation stress in the triaxial test) in an attempt to overcome the effects of disturbance, and to normalize the shear strength with respect to $\sigma_{c}^{\prime}$, to yield the ratio $\mathrm{S}$ (the ratio of shear strength $\left[\mathrm{S}_{u}\right]$ to $\sigma_{c}^{\prime}\left[\mathrm{S}_{u}=q / 2\right.$, where $q=$ the deviatoric stress, defined as $\left.\sigma_{1}^{\prime}-\sigma_{3}^{\prime}\right]$ ). Also, if the sediments sampled are assumed to be lithologically similar to those at greater depths, then the method can be used to predict the in situ shear strength profile, and therefore the sediment stability, deeper in the sediment column.

The samples were tested at Cardiff University using a Wykeham Farrance Ltd. triaxial rig following the procedures of Bishop and Henkel (1962) and Head (1986). The data were recorded using an electronic data logger attached to a microcomputer and printer. Samples were first subjected to a "B" value (Skempton, 1954) test to ensure complete saturation and were then isotropically consolidated 
to approximately four times $\sigma_{v m}^{\prime}$ (to induce an OCR of 1) and finally sheared over a period long enough to allow complete equalization of pore pressures. During undrained shear axial load, axial displacement and pore pressure were measured and recorded. Using these data, stress-strain and stress path plots were produced (in the Cambridge stress field: $p^{\prime}=$ the mean all round effective stress,

$$
\frac{\sigma^{\prime}{ }_{1}+2 \sigma_{3}^{\prime}}{3}
$$

and $q=$ the deviatoric stress). Failure points were chosen as either the peak deviatoric stress, the deviatoric stress at the critical state (see Roscoe et al., 1958; Schofield and Wroth, 1968), or the deviatoric stress at a limiting strain of $20 \%$, dependent on the shape of the stress-strain curve. The shear strength $\left(S_{u}\right)$ was then normalized; it can be related to the in situ shear strength using the following equation modified from Ladd et al. (1977):

$$
\frac{S_{u}}{\sigma_{v}^{\prime}}=S(O C R)^{\wedge}
$$

where $S_{u}=$ undrained shear strength $(\mathrm{kPa})$, and $\Lambda=$ a sediment constant relating OCR to normalized strength.

The parameter $\Lambda$ is assumed to have a value of 0.84 , as reported by Hamilton (1989) from tests on similar sediments in the Gulf of Alaska. Equation 1 was modified to Equation 2 by Lee and Edwards (1986) to correct the calculation for anisotropic consolidation (the field situation) and cyclic strength degradation (loss of strength because of cyclic loading). The former correction factor was not measured, but a value of 0.8 has been used previously after a comprehensive survey of published data by Mayne (1985). The Marine Geotechnical Consortium (1985) conducted several anisotropically consolidated triaxial tests (CAU) on samples from Deep Sea Drilling Project (DSDP) Hole 576A of Leg 86 and found that the values of shear strength were $89 \%$ of those for isotropically consolidated (CIU) samples; the sediments tested in this case, however, were red clays. In this study, therefore, a value of 0.8 was used. A cyclic strength degradation factor was not determined, and a value of 1 is used throughout this study.

$$
\frac{S_{u}}{\sigma_{v}^{\prime}}=A_{c} A_{r} S(O C R)^{\wedge},
$$

where $A_{c}=$ correction for anisotropic consolidation ( $\left.=0.8\right)$, and $A_{r}=$ cyclic strength degradation factor $(=1)$.

\section{Slope Stability Analysis}

Sediment stability was assessed using the infinite slope theory balancing the forces acting on a unit length of slope (Taylor, 1948). Into the balancing equations, a horizontal ground acceleration can be introduced to account for seismic loading, to yield the following, as proposed by Morgenstern (1967):

$$
\frac{S_{u}}{\gamma_{z}^{\prime}}=0.5 \sin (2 \alpha)+k \frac{\gamma}{\gamma^{\prime}} \cos ^{2}(\alpha),
$$

where $\alpha=$ slope angle $\left({ }^{\circ}\right), \gamma=$ total unit weight $\left(\mathrm{kNm}^{-3}\right), \gamma^{\prime}=$ effective unit weight $\left(\mathrm{kNm}^{-3}\right)$, and $k=$ horizontal ground acceleration (percentage of gravity).

If Equation 3 is set equal to Equation 2 and is solved for $k$, then a critical ground acceleration (i.e., for failure) can be calculated.

$$
k=\frac{\gamma^{\prime}}{\gamma}\left[A_{c} A_{r} S(O C R)^{\wedge}-\sin \alpha\right],
$$

after simplification for small angles of slope (less than $10^{\circ}$ ).

The disadvantage of this method is that earthquakes produce vertical as well as horizontal ground accelerations. It has been suggested, however, that the effect of such vertical movements is less significant, as they are damped by the water overburden pressures (Kastens, 1984).

\section{RESULTS}

\section{Shipboard Measurements}

The results of the shipboard measurements are presented in Figure 1 on a composite depth scale constructed using the gamma-ray attenuation and porosity evaluator (GRAPE) and magnetic susceptibility records (see Roberts, 1994). The index properties show the expected interrelationships, with water content and porosity exhibiting fairly similar profiles, and the wet bulk density plot mirroring these. Water contents are generally high (notably below $34 \mathrm{~m}$ composite depth, where they are sometimes in excess of $300 \%$ dry weight) and correspond to lower values of wet bulk density. Variations in the index properties profiles are most likely the result of changes in sediment composition, in which the diatom-rich sediments are generally less dense and have higher water contents. The shear strength of the sediment steadily increases downhole, but there is a transition zone at $\approx 18 \mathrm{~m}$ composite depth and a break of slope at $\approx 24 \mathrm{~m}$ composite depth. In addition to the smear slide descriptions conducted onboard, the samples tested in this study have been described, and the results are presented in Table 1.

\section{Consolidation Tests}

Table 2 gives a summary of the results from the consolidation tests performed. The void ratio vs. log effective stress curves (Fig. 2) are representative of disturbed samples, with flattened curves. The virgin compression line is not fully developed in any of the plots as loading was terminated at $800 \mathrm{kPa}$; this makes the estimation of $\sigma_{v m}^{\prime}$ difficult and somewhat subjective. The values of $c_{y}$ (ranging from 1.05 to 1.84 $\times 10^{-2} \mathrm{~cm}^{2} \mathrm{~s}^{-1}$ ) are minimum estimates because of the very rapid primary consolidation of all the samples tested. This also means that the calculated permeabilities are minimum values $\left(6.1\right.$ to $\left.19 \times 10^{-9} \mathrm{~ms}^{-1}\right)$, and are probably up to an order of magnitude lower than measured permeabilities would be for these sediment types, as observed by the Marine Geotechnical Consortium (1985), Pittenger et al. (1989), and Bryant and Rack (1990). The coefficients of volume compressibility $\left(m_{v}\right)$ range from 0.41 to $1.54 \mathrm{~m}^{2} \mathrm{MN}^{-1}$, which are indicative of highly compressible sediments. The compression indices range from 0.65 to 1.38 (moderate to highly compressible) and are generally within the ranges reported by Hampton (1989) and Searle et al. (1985) from the Gulf of Alaska and the North East Atlantic, respectively. The highest $C_{c}$ value of 1.38 (Sample 145-883A-3H-3, 130-140 cm) indicates that relatively large amounts of settlement may occur under a particular load; this value is higher than the values given by Hamilton (1989).

The OCR is plotted against composite depth in Figure 3 along with the ratio of vane shear strength to overburden pressure $\left(S_{u} / \sigma_{v}^{\prime}\right)$ which can be used to estimate the stress state of a soil (a value of between 0.2 and 0.5 represents normally consolidated sediments; Skempton, 1970). These profiles show that the sediments become normally consolidated at a composite depth of $25 \mathrm{~m}$ based on the OCR profile and at approximately $20-25 \mathrm{~m}$, based on the vane $\mathrm{S}_{u} / \sigma_{v}^{\prime}$ curve. The sediments are also normally consolidated at much greater depths ( 86.8 and $456.1 \mathrm{mbsf}$; see Rutledge et al., this volume). There is no geological evidence to suggest that the overconsolidation in the upper few meters is real (i.e., no erosional events to unload the sediment pile); therefore, the overconsolidation is assumed to be apparent (i.e., caused by interparticulate bonding, bioturbation, or cementation processes).

\section{Triaxial Tests}

The triaxial test results are summarized in Table 3. Two examples of the stress-strain and $p^{\prime}-q$ plots are shown in Figure 4: the plots are for Samples 145-883A-2H-1, 130-140 cm, and -2H-5, 130-140 cm, a diatom ooze and an ash layer, respectively. The stress-strain curves 

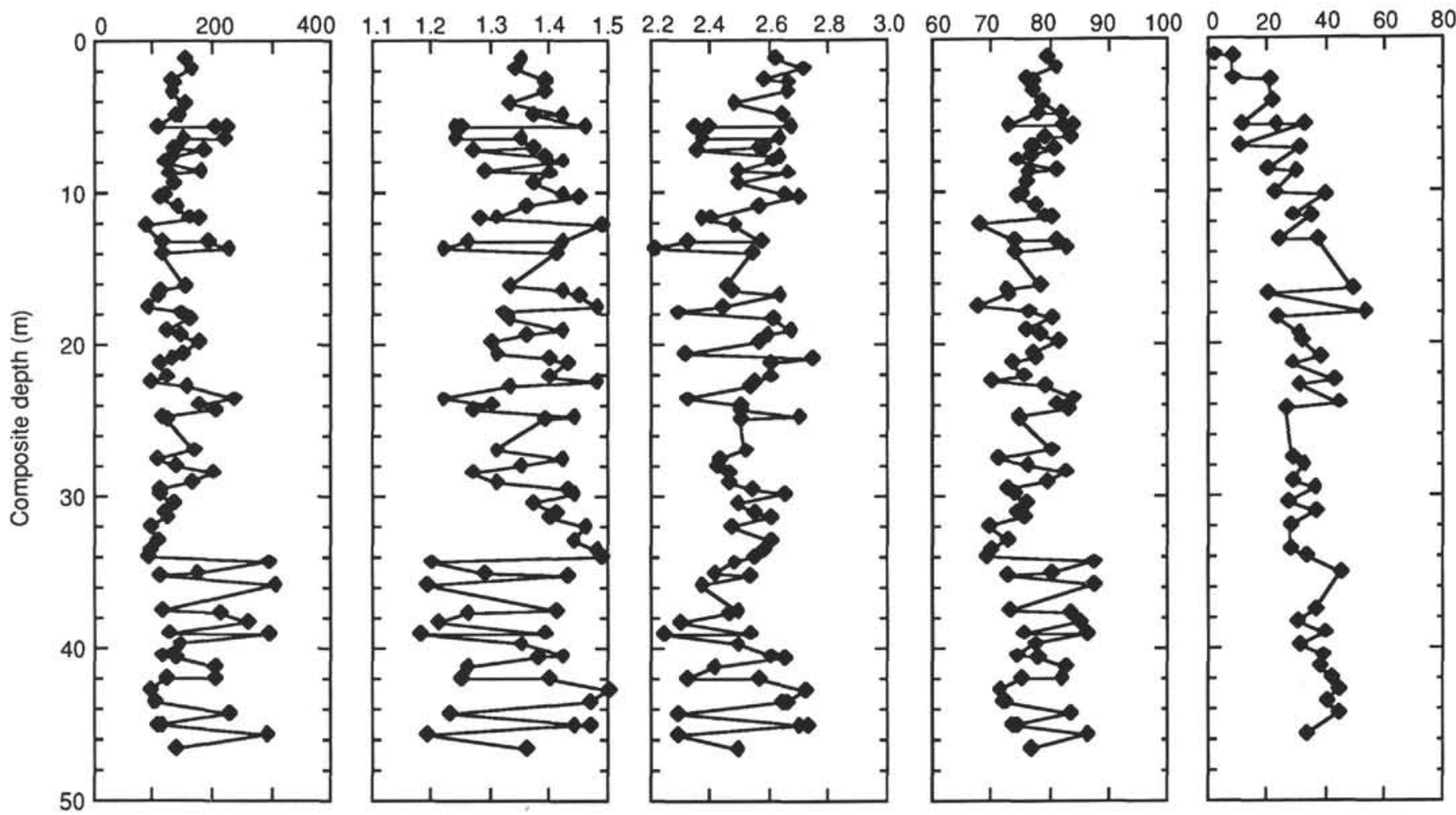

Figure 1. Graphs of index properties and vane shear strength measured aboard the JOIDES Resolution and plotted on a composite depth scale, Site 883.

Table 1. Results of smear slide analyses on samples from Site $\mathbf{8 8 3}$ (values are given as percentages).

\begin{tabular}{|c|c|c|c|c|c|c|c|c|}
\hline $\begin{array}{l}\text { Hole, core, } \\
\text { section }\end{array}$ & $\begin{array}{l}\text { Composite } \\
\text { depth } \\
\text { (m) }\end{array}$ & Diatoms & Spicules & Radiolarians & Clay & Quartz & Ash & $\begin{array}{c}\text { Carbonate } \\
\text { particles }\end{array}$ \\
\hline $883 \mathrm{~B}-1 \mathrm{H}-2$ & 2.85 & 30 & 5 & tr & 60 & $\operatorname{tr}$ & - & 5 \\
\hline $883 \mathrm{~A}-1 \mathrm{H}-2$ & 7.35 & 35 & 5 & tr & 60 & tr & - & tr \\
\hline $883 \mathrm{~A}-2 \mathrm{H}-1$ & 17.05 & 60 & tr & tr & 30 & tr & - & 10 \\
\hline $883 \mathrm{~A}-2 \mathrm{H}-5$ & 23.05 & 5 & - & - & - & tr & 95 & \\
\hline $883 \mathrm{~A}-3 \mathrm{H}-3$ & 30.95 & 85 & 5 & - & 10 & tr & - & - \\
\hline $883 \mathrm{~A}-4 \mathrm{H}-1$ & 38.65 & 85 & tr & - & 5 & 5 & - & 5 \\
\hline $883 \mathrm{~A}-4 \mathrm{H}-5$ & 44.55 & 85 & 5 & - & 10 & - & - & tr \\
\hline
\end{tabular}

Note: $\mathrm{tr}=$ trace quantities, and dash $(-)=$ not present.

Table 2. Results of consolidation tests performed on samples from Site 883.

\begin{tabular}{ccccccccc}
\hline $\begin{array}{c}\text { Hole, core, } \\
\text { section }\end{array}$ & $\begin{array}{c}\text { Composite } \\
\text { depth } \\
(\mathrm{m})\end{array}$ & $\begin{array}{c}c_{v}\left(\times 10^{-2}\right) \\
\left(\mathrm{cm}^{2} \mathrm{~s}^{-1}\right)\end{array}$ & $\begin{array}{c}m_{v} \\
\left(\mathrm{~m}^{2} \mathrm{MN}^{-1}\right)\end{array}$ & $\begin{array}{c}k\left(\times 10^{-9}\right) \\
\left(\mathrm{ms}^{-1}\right)\end{array}$ & $C_{c}$ & $\begin{array}{c}\sigma_{v}^{*} \\
(\mathrm{kPa})\end{array}$ & $\begin{array}{c}\sigma_{v \text { vin }} \\
(\mathrm{kPa})\end{array}$ & OCR \\
\hline $883 \mathrm{~B}-1 \mathrm{H}-2$ & 2.95 & 1.05 & 1.04 & 11 & 1.09 & 10.2 & 96 & 9.4 \\
$883 \mathrm{~A}-1 \mathrm{H}-2$ & 7.45 & 1.24 & 1.54 & 19 & 0.75 & 25 & 58 & 2.3 \\
$883 \mathrm{~A}-2 \mathrm{H}-1$ & 17.15 & 1.55 & 0.69 & 11 & 0.96 & 57.5 & 140 & 2.4 \\
$883 \mathrm{~A}-\mathrm{H}-5$ & 23.15 & 1.43 & 0.86 & 12 & 0.83 & 78 & 105 & 1.3 \\
$883 \mathrm{~A}-3 \mathrm{H}-3$ & 30.85 & 1.84 & 0.76 & 14 & 1.38 & 101 & 142 & 1.4 \\
$883 \mathrm{~A}-4 \mathrm{H}-1$ & 38.55 & 1.49 & 0.48 & 7 & 0.87 & 124 & 153 & 1.2 \\
$883 \mathrm{~A}-4 \mathrm{H}-5$ & 44.65 & 1.52 & 0.41 & 16.1 & 0.65 & 141 & 157 & 1.1 \\
\hline
\end{tabular}

Note: Values of $c_{v}, m_{v}$ and $k$ are given for the preconsolidation pressure (as determined using the Casagrande technique).

show increasing deviatoric stress until failure, at which point there is a decrease in the deviatoric stress, which, in the case of Sample 145-883 A-2H-1, 130-140 cm, follows the critical state line. The ash sample was sheared up to relatively high deviatoric stresses, yielding a high $S$ ratio, but we suspect that the sample was not consolidated into the normally consolidated range before the shearing stage of the test. This is borne out by the pore pressure coefficient $A$ at failure, which has a value of $<0.1$ (see Skempton, 1954), indicative of an overconsolidated sediment. Five of the seven samples tested exhibit plastic deformation (barreling), except for the two samples illustrated in Figure 4 that failed along distinct shear planes after initially barrelling. Generally, the stress-strain curves show monotonically increas- 
Table 3. Results of CIU triaxial test performed on samples from Site $\mathbf{8 8 3 .}$

\begin{tabular}{|c|c|c|c|c|c|c|c|c|c|c|c|c|}
\hline $\begin{array}{l}\text { Hole, core, } \\
\text { section }\end{array}$ & $\begin{array}{c}\text { Composite } \\
\text { depth } \\
\text { (m) }\end{array}$ & $\begin{array}{l}\text { Sediment } \\
\text { type }\end{array}$ & $\begin{array}{l}w_{i} \\
(\%)\end{array}$ & $\begin{array}{l}w_{f} \\
(\%)\end{array}$ & $\begin{array}{c}\text { Vane } \\
\text { strength } \\
\text { (kPa) }\end{array}$ & $\begin{array}{c}\sigma_{i m}^{\prime} \\
(\mathrm{kPa})\end{array}$ & $\begin{array}{c}\sigma_{c}^{\prime} \\
(\mathrm{kPa})\end{array}$ & $\begin{array}{c}\text { Induced } \\
\text { OCR }\end{array}$ & $\begin{array}{l}\varepsilon_{f} \\
(\%)\end{array}$ & $\begin{array}{c}q_{f} \\
(\mathrm{kPa})\end{array}$ & $\begin{array}{c}S_{a} \\
(\mathrm{kPa})\end{array}$ & $S$ \\
\hline 883B-IH-2 & 2.85 & Clay & 137 & 71 & 21.4 & 96 & 419.1 & I & 15.3 & 410.9 & 205.5 & 0.49 \\
\hline $883 \mathrm{~A}-1 \mathrm{H}-2$ & 7.35 & Clay & 123 & 75 & 20.8 & 58 & 228 & i & 20 & 253.4 & 126.7 & 0.56 \\
\hline $883 \mathrm{~A}-2 \mathrm{H}-1$ & 17.05 & Diatom ooze & 145 & 93 & 40.8 & 140 & 598.9 & 1 & 13.3 & 631.5 & 315.8 & 0.53 \\
\hline $883 \mathrm{~A}-2 \mathrm{H}-5$ & 23.05 & Ash & 110 & 47 & 37.5 & 105 & 419.5 & i & 16.2 & 1475.8 & 737.9 & 1.76 \\
\hline $883 \mathrm{~A}-3 \mathrm{H}-3$ & 30.95 & Diatom ooze & 157 & 82 & 32.1 & 142 & 591.2 & i & 20 & 664.1 & 332.1 & 0.56 \\
\hline $883 \mathrm{~A}-4 \mathrm{H}-1$ & 38.65 & Diatom ooze & 134 & 82 & 35.0 & 153 & 594.6 & i & 20 & 594.4 & 297.2 & 0.50 \\
\hline $883 \mathrm{~A}-4 \mathrm{H}-5$ & 44.55 & Diatom ooze & 111 & 72 & 38.8 & 157 & 597.1 & $\mathrm{i}$ & 20 & 737.6 & 368.8 & 0.62 \\
\hline
\end{tabular}

Note: Subscript $f=$ failure condition.

Figure 2. Void ratio vs. log effective stress plots for samples from Site 883.
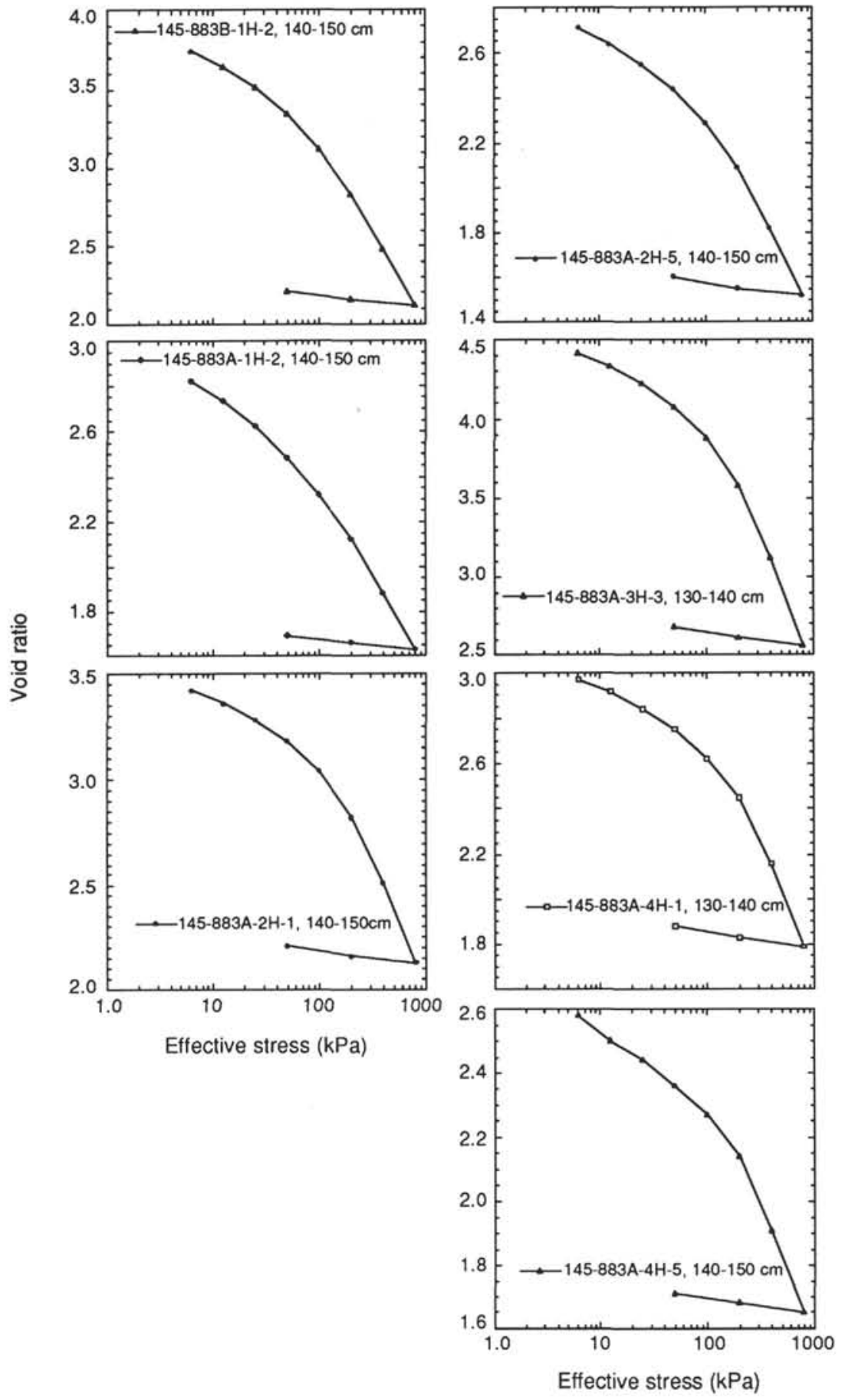
ing deviatoric stress, leveling off at about $5 \%$ to $10 \%$ axial strain, and the strains at failure $\left(\varepsilon_{f}\right)$ range from $13 \%$ to $20 \%$.

The average value of $S$ (excluding the results from Sample 145$883 \mathrm{~A}-2 \mathrm{H}-5,140-150 \mathrm{~cm}$, which is an ash layer) has been used to produce an estimate of the in situ strength profile using the normalized strength parameter (NSP) relationship given by Equation 2, and is shown in Figure 5 with the vane shear strength profile. The NSP 1 profile (assuming OCR $=1$ ) gives a good approximation to the vane shear strength plot in the upper part of the sampled section down to $24 \mathrm{~m}$ composite depth; below this depth, the NSP 1 strength estimate yields higher values than the vane shear strength profile. The higher values may be either the result of core disturbance or expansion of the cores (porosity rebound) from greater depths (yielding lower vane shear strengths), or of apparent overconsolidation in the upper $24 \mathrm{~m}$ of sediment, which is not accounted for in the NSP 1 calculation. Figure 5 presents a second profile of NSP shear strength (NSP 2) based on the data for individual test samples, and accounting for the apparent overconsolidation determined from oedometer test results. This curve shows that the apparent overconsolidation in the upper few meters does not have a great effect on the NSP strength profile, suggesting that core disturbance or porosity rebound account for the lower vane shear strengths below $24 \mathrm{~m}$ depth. The peak in the NSP 2 plot corresponds to the ash layer (Sample 145-883A-2H-5, 140-150 cm), which yielded a very high value of $S$. This peak is not seen in the vane shear strength profile because only dominant lithologies were tested for vane shear strength, (i.e., not ash layers). The peak may also be the result of testing the ash sample at a confining pressure $\left(\sigma_{c}^{\prime}\right)$ too low to produce normal consolidation and thus yielding a higher $\mathrm{S}$ ratio.

\section{Slope Stability Analysis}

The slope angles used in the analyses were measured from the seismic profiles recorded during Leg 145, first for the top of the Detroit Seamount (at Site $883, \approx 0.7^{\circ}$ ) and second on the flanks of the Detroit Seamount (up to $8^{\circ}$ ). The vane shear strength data have been used in Equation 3 (Table 4) and data derived from the triaxial tests were used in Equation 4 (Table 5), to assess the slope stability of the sediments.

Using the vane shear strength data, critical ground accelerations can be calculated for specific depths in the sediment column. This type of analysis estimates that the sediments are least stable at a depth of $40 \mathrm{~m}$. Critical ground accelerations of $3 \%$ and $6 \%$ of gravity may be sufficient to fail the sediments at the $40 \mathrm{~m}$ interval, on the flanks of the seamount and at Site 883 , respectively.

Based on the triaxial testing results the analyses show that the diatom- and clay-rich sediments on the seamount flanks are unstable when subjected to earthquakes producing ground accelerations in excess of $7 \%$ to $8 \%$ of gravity but the ash layers are much more stable (at ground accelerations up to $52 \%$ of gravity). At Site 883 , where the slopes are less steep, the sediments are more stable (up to ground accelerations of $10 \%-11 \%$ of gravity). There is little difference in the stability of the ash layers at the summit of the Detroit Seamount, where only very large ground accelerations will cause failure $(57 \%$ of gravity).

\section{DISCUSSION}

It has been suggested that siliceous sediments may represent planes of weakness in a sediment pile (Pittenger et al., 1989). In this study, however, both clay- and diatom-rich sediments have been tested, both yielding very similar values for shear strength (through the NSP approach), suggesting that the diatom-rich sediments are no stronger or weaker than the clay-rich sediments even though siliceous sediments are generally reported to have lower vane shear strengths (Bryant et al., 1981). The triaxial tests in this study were conducted in an undrained condition and thus may not be representative of the type of failure that could occur in the sediments. If drained failure were to occur (although unlikely according to Morgenstern, 1967), then permeability would be

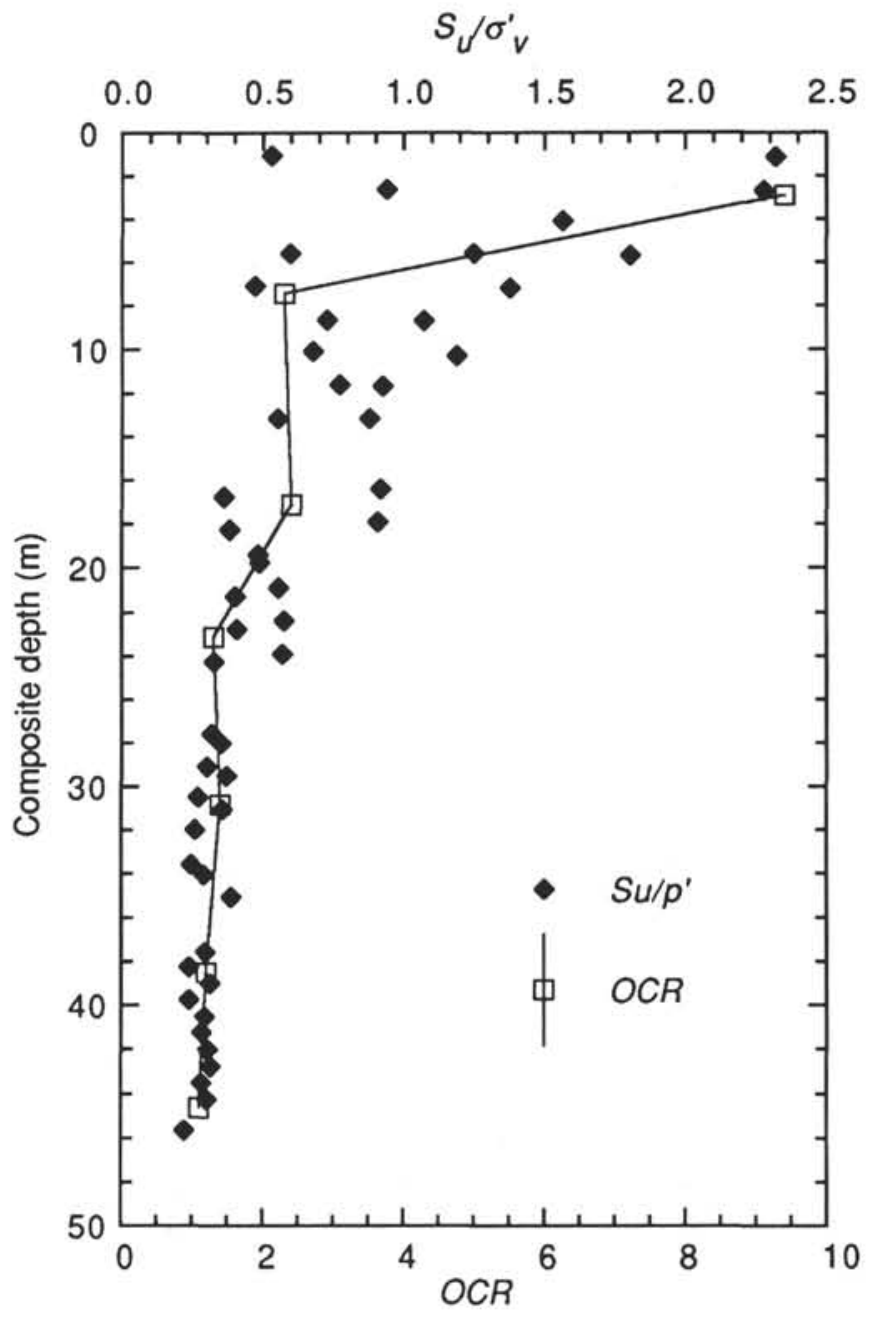

Figure 3. Graph of vane $S_{u} / \sigma_{v}^{\prime}$ and OCR on a composite depth scale. Values of vane $S_{u} / \sigma_{v}^{\prime}$ between 0.2 and 0.5 generally represent normal consolidation (Skempton, 1970).

Table 4. Results of slope stability analysis on the basis of vane shear strength data.

\begin{tabular}{ccccccc}
\hline $\begin{array}{c}\text { Composite } \\
\text { depth } \\
(\mathrm{m})\end{array}$ & $\gamma^{\prime} / \gamma^{\prime}$ & $\begin{array}{c}\sigma_{v}^{\prime} \\
(\mathrm{kPa})\end{array}$ & $\begin{array}{c}S_{u} \\
(\mathrm{kPa})\end{array}$ & $S_{u^{\prime}} / \sigma_{v}^{\prime}$ & $\begin{array}{c}\left(\alpha=0.7^{\circ}\right) \\
k \text { required } \\
\text { for failure }\end{array}$ & $\begin{array}{c}\left(\alpha=8^{\circ}\right) \\
k \text { required } \\
\text { for failure }\end{array}$ \\
\hline 5 & 0.25 & 17.3 & 22.3 & 1.29 & 0.32 & 0.29 \\
10 & 0.28 & 32.4 & 26.0 & 0.80 & 0.22 & 0.19 \\
15 & 0.27 & 44.9 & 43.2 & 0.96 & 0.26 & 0.23 \\
20 & 0.21 & 64.6 & 31.5 & 0.49 & 0.10 & 0.08 \\
25 & 0.26 & 81.3 & 27.4 & 0.34 & 0.09 & 0.05 \\
30 & 0.29 & 98.1 & 31.7 & 0.32 & 0.09 & 0.05 \\
35 & 0.21 & 116.6 & 39.3 & 0.34 & 0.07 & 0.04 \\
40 & 0.26 & 130.0 & 31.1 & 0.24 & 0.06 & 0.03 \\
45 & 0.30 & 148.5 & 44.1 & 0.30 & 0.09 & 0.05 \\
\hline
\end{tabular}

a very important factor in assessing the sediment stability, therefore the sediment composition may have a more pronounced effect.

The seismicity of the region for the last century is shown in Figure 6 (a $10^{\circ}$ box centered on Site 883 ). The three strongest earthquakes in the area were of magnitudes between 7.5 and 8.0, and about $300-350$ $\mathrm{km}$ away from Site 883 . The earthquakes occurred in September 1905, September 1907, and December 1929 (marked 1, 2, and 3 in Fig. 6), producing ground accelerations (calculated using the equations of Burton, 1978) at Site 883 of $<1 \%$ of gravity. There have been 

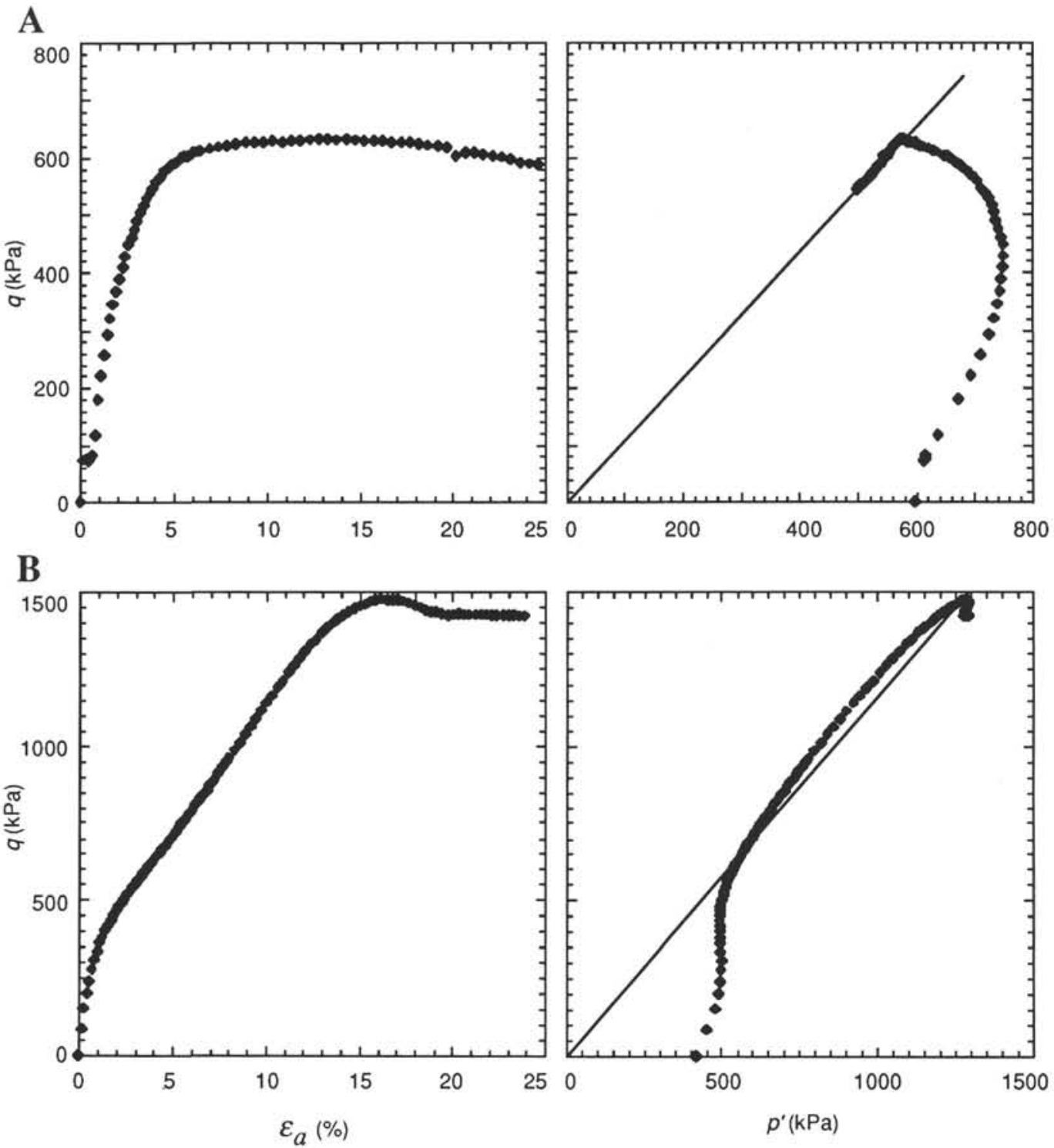

Figure 4. Examples of the stress-strain and $p^{\prime}-q$ plots for Samples 145-883A-2H-1, 130-140 cm (A) and 145-883A-2H-5, 130-140 cm (B), a diatom ooze and an ash, respectively.

Table 5. Results of slope stability analysis on the basis of CIU triaxial test data using the NSP approach.

\begin{tabular}{|c|c|c|c|c|c|c|c|c|}
\hline $\begin{array}{l}\text { Sediment } \\
\text { type }\end{array}$ & $\gamma^{\prime} / \gamma^{\prime}$ & OCR & $A_{c}$ & $A_{r}$ & $s$ & $\Lambda$ & $\begin{array}{l}\left(\alpha=0.7^{\circ}\right) \\
k \text { required } \\
\text { for failure }\end{array}$ & $\begin{array}{c}\left(\alpha=8^{\circ}\right) \\
k \text { required } \\
\text { for failure }\end{array}$ \\
\hline Clay & 0.27 & 1 & & & 0.53 & & 0.11 & 0.08 \\
\hline Diatom ooze & 0.24 & 1 & 0.8 & 1 & 0.55 & 0.84 & 0.10 & 0.07 \\
\hline Ash & 0.41 & 1 & & & 1.76 & & 0.57 & 0.52 \\
\hline
\end{tabular}

smaller earthquakes nearer the Detroit Seamount (of about 5 in magnitude) that may have a more significant impact on sediment stability; in particular, one earthquake $33 \mathrm{~km}$ to the north of Site 883 produced ground accelerations in excess of $10 \%$ of gravity.

The results indicate that the clay- and diatom-rich sediments on the Detroit Seamount require relatively small ground accelerations to induce failure when compared with data from other areas in the Pacific Ocean. For example, Lee and Edwards (1986) reported a critical ground acceleration of $14 \%$ of gravity separating the stable from the unstable sediments in areas in the Gulf of Alaska and off the coast of California on slopes ranging from $0.5^{\circ}$ to $5^{\circ}$. Also Hampton (1989) calculated a critical ground acceleration of $11 \%$ of gravity for apparently stable terrigenous sediments on a $7^{\circ}$ slope.

The seismic survey data from the Detroit Seamount area gives no direct evidence of slumping and/or slide scars, in contrast to interpreted side-scan survey data from an area to the south $\left(\approx 5^{\circ}\right.$ farther south), still in the Emperor chain, which does show classic evidence of slides and slumps (D. Rea, pers. comm., 1994). This more south- 
erly area appears to be seismically less active than the Detroit Seamount region (see Fig. 6). Indirect evidence is present, such as channels, that suggests downslope sediment movement has taken place at the Detroit Seamount. In addition, higher sediment accumulation rates occurred at Sites 882 and 884 , in deeper water, relative to Site 883. There still remains, however, an apparent lack of large-scale downslope movement, if the values of $k$ from this study and the estimated ground accelerations from the historical seismic records are assumed to be correct.

Low values for $k$ could be explained by our use of a cyclic loading correction factor $\left(A_{r}\right)$ of unity in the stability equations, which probably does not represent the high water content sediments sampled. Lee and Edwards (1986) found that $A_{r}$ increased with water content and reached values of unity at quite low water contents $(55 \%$ for sediments from the Gulf of Alaska and $85 \%$ for sediments from the Californian margin). Therefore, using an $A_{r}$ of 1 in Equation 4 yields an underestimation of the ground accelerations required for failure.

Moving on from the analysis of sediment stability, what would happen to the sediments if they failed? Schwab and Lee (1988) considered sediment behavior during static CIU triaxial testing to predict the morphology of downslope movement after initial sediment failure using the State I and State II definitions of sediment from Whitman (1985) (see Fig. 7) and the concept of steady state deformation (Poulos, 1981). The definition of the steady state is similar to that of the critical state, but when the sediment is totally remolded and continuously deforming at constant velocity, constant effective stress, and constant volume; these conditions are usually only met at large strains. State I sediments are characterized by contractive behavior (the sediment framework tends to collapse during shear) and a steady state strength $\left(q_{s s}\right)$ less than the in situ gravitational stress $\left(q_{s}\right)$, and State II sediments are characterized by mildly contractive to dilative behavior (the sediment framework tends to expand during shear) and a steady state strength greater than the in situ gravitational stress. According to Whitman (1985), only sediments in State I will, after failure, develop into disintegrative failures (sediment gravity flows), whereas State II sediments develop nondisintegrative failures (slumps or slides).

The stress path plots of the sediments tested in this study are shown in Figure 8. The majority of these samples exhibit State II behavior, with monotonically increasing $q$. One sample $(145-883 \mathrm{~A}-2 \mathrm{H}-1,140-150 \mathrm{~cm})$ can be defined as a State I sediment (monotonically decreasing $p^{\prime}$ ); this is composed of clay and diatom ooze. It is unlikely that a State II sediment can be converted into a State I sediment by earthquake loading alone (Schwab and Lee, 1988), as the development of a shear plane would reduce the effects of cyclic stresses on the sediments above such a plane. A shear plane would reduce the effect of jostling or agitation that could cause an ingress of water, thus expanding the sediment framework and possibly causing a conversion from a State II to State I sediment (see discussion by Hampton, 1972; Schwab and Lee, 1988). It seems unlikely, therefore, that if these sediments failed, a sediment gravity flow would be produced.

\section{CONCLUSIONS}

The vane shear strength profiles are a good approximation of the in situ shear strength (as estimated using the NSP approach) for relatively undisturbed core material in the upper $25 \mathrm{~m}$ of the sediment column.

The clay- and diatom-rich sediments have $\mathrm{S}$ ratios of $0.49-0.56$ and $0.50-0.62$, respectively. The variation in normalized strength with sediment composition is relatively small, and there is little effect on sediment stability.

The sediments sampled (excluding ashes; e.g., Sample 145-883A$2 \mathrm{H}-1,130-140 \mathrm{~cm}$ ) are stable when affected by earthquake ground accelerations $<11 \%$ of gravity on the top of the Detroit Seamount; however, on the flanks this is reduced to $8 \%$ of gravity.

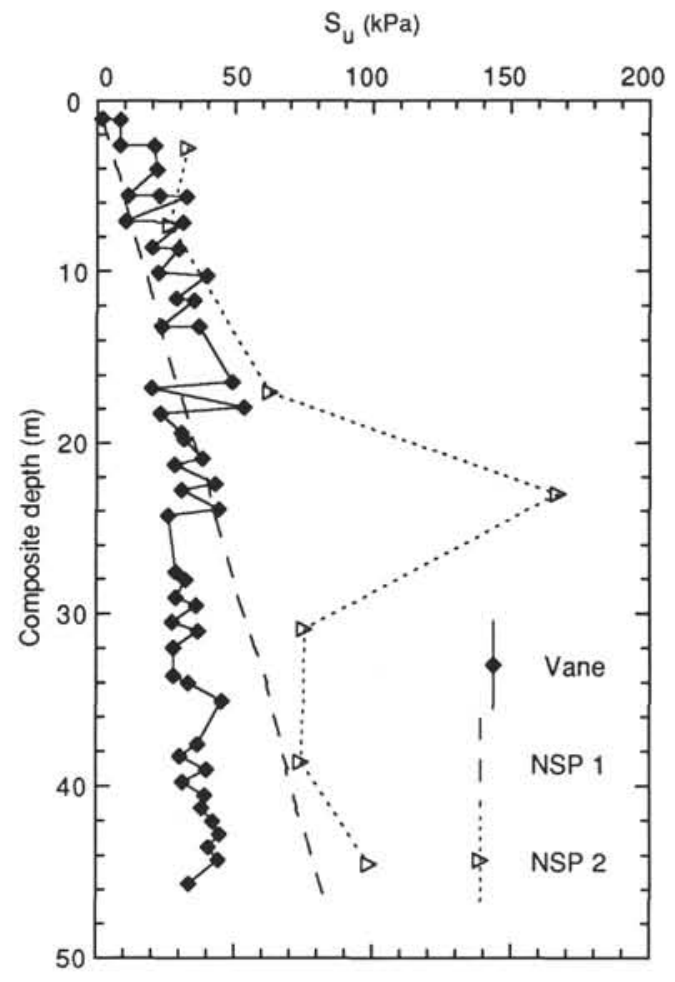

Figure 5. Graph showing vane shear strength and NSP estimates (see text) of shear strength on a composite depth scale.

Seismicity in the region is high, but only very large or proximal earthquakes may affect the stability of sediments on the Detroit Seamount. The relative susceptibility to failure determined in this study is probably conservative because of the use of a cyclic degradation factor of unity, and is probably not representative of sediments with such high water contents.

The stress path plots show that the sediments can generally be defined as State II, but one sample has State I characteristics. It is unlikely, therefore, that sediment failure on the Detroit Seamount will produce disintegrative failures (i.e., sediment gravity flows) unless the sediment framework is expanded by the ingress of pore waters through some mechanism. This may occur by jostling or agitation of the sediment during movement (Hampton, 1972), or perhaps by the setting up of pore pressure gradients as the seabed is overridden by failed sediment from above (progressive failure as defined by Moore, 1961).

To assess the sediment stability of the area more quantitatively requires two procedures: (1) analyze sediments from in and around a known slope failure to evaluate a critical $k$ value separating failed and stable material, and (2) determine a cyclic strength degradation factor representative of the samples tested; this could be achieved using the methodologies of Schwab and Lee (1983).

\section{ACKNOWLEDGMENTS}

Participation of the authors on Leg 145 was funded by NERC and SERC, USSAC, and the ESF, respectively. Thanks are extended to Buckey Turk in the Department of Civil Engineering, TAMU, Len Czecaj and Debbie Ward in the Department of Engineering, Cardiff, Paul Henni at the British Geological Survey (Edinburgh), and the staff and scientists aboard the JOIDES Resolution during Leg 145. Elliot Taylor and Frank Rack are thanked for their critical reviews which have greatly improved this manuscript. 


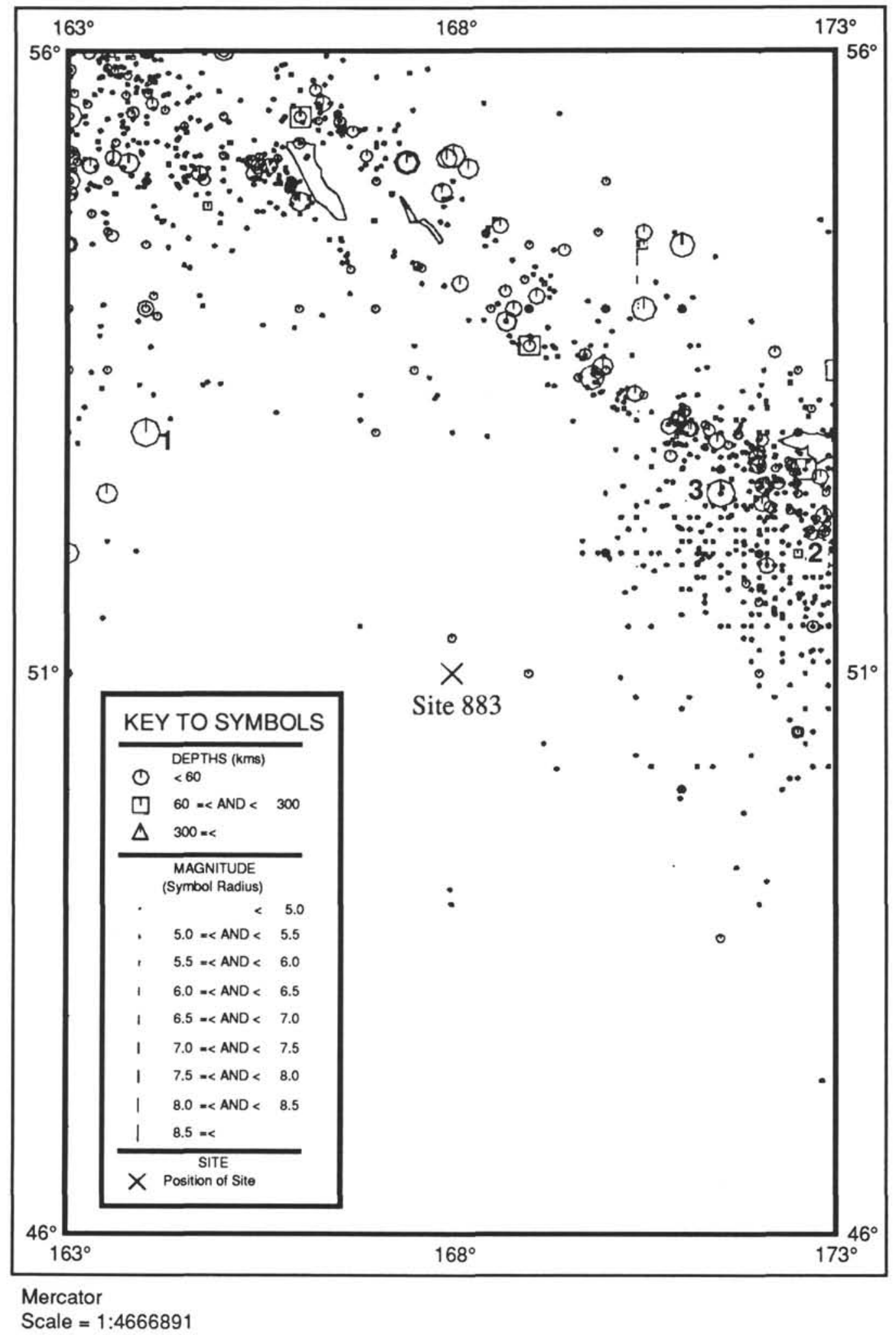

Figure 6. Chart of a $10^{\circ}$ box centered on Site 883 showing the seismicity of the area during the last century. The three largest earthquake epicenters are marked 1 , 2, and 3 (see text). Courtesy of Paul Henni, British Geological Survey, Edinburgh. 

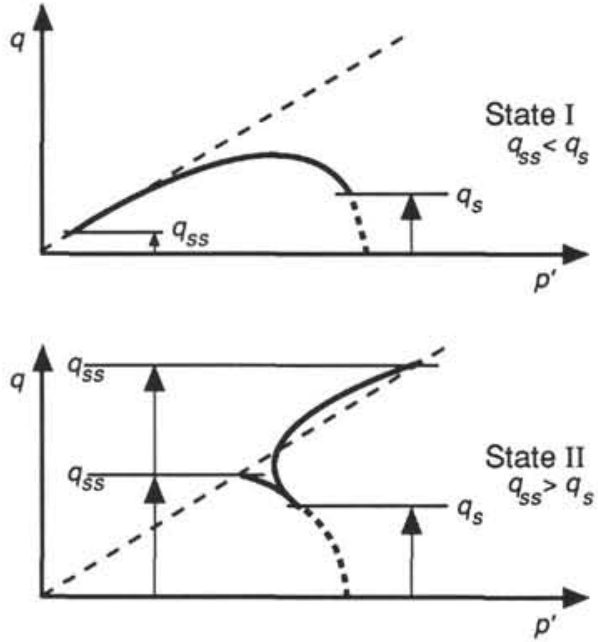

Figure 7. Effective stress paths representative of State I and II sediments (after Whitman, 1985).

\section{REFERENCES}

Bishop, A.W., and Henkel, D.J., 1962. The Measurement of Soil Properties in the Triaxial Test: London (Edward Arnold).

British Standards (BS) 1377, 1975. Methods of Test for Soils for Civil Engineering Purposes: London (British Standards Institution).

Bryant, W.R., and Rack, F.R., 1990. Consolidation characteristics of Weddell Sea sediments: results of ODP Leg 113. In Barker, P.F., Kennett, J.P., et al., Proc. ODP, Sci. Results, 113: College Station, TX (Ocean Drilling Program), 211-223.

Bryant, W.R., Bennett, R.H., and Katherman, C.E., 1981. Shear strength, consolidation, porosity and permeability of ocean sediments. In Emiliani, C. (Ed.), The Sea (Vol. 7): Oceanic Lithosphere: New York (Wiley), 1555-1616.

Burton, P.W., 1978. The IGS file of seismic activity and its use for hazard assessment. Seismol. Bull. Inst. Geol. Sci., 6.

Casagrande, A., 1936. Determination of preconsolidation load and its practical significance. Proc. 1st Conf. Soil Mech. and Foundation Eng., Am. Soc. Civ. Eng., 3:60-64.

Embley, R.W., 1976. New evidence for occurrence of debris flow deposits in the deep sea. Geology, 4:371-374.

Hampton, M.A., 1972. The role of subaqueous debris flow in generating turbidity currents. J. Sediment. Petrol., 42:775-793.

, 1989. Geotechnical properties of sediment on the Kodiak continental shelf and upper slope, Gulf of Alaska. Mar. Geotechnol., 8:159-180.

Head, K.H., 1982. Manual of Soil Laboratory Testing (Vol. 2): Permeability, Shear Strength and Compressibility Tests: London (Pentech Press).

, 1986. Manual of Soil Laboratory Testing (Vol. 3): Effective Stress Tests: London (Pentech Press).

Kastens, K.A., 1984. Earthquakes as a triggering mechanism for debris flows and turbidites on the Calabrian Ridge. Mar: Geol., 55:13-33.

Ladd, C.C., and Foott, R., 1974. A new design procedure for stability of soft clays. J. Geotech. Eng. Div., Am. Soc. Civ. Eng., 100:763-786.

Ladd, C.C., Foott, R., Ishihara, K., Schlosser, F., and Poulos, H.G., 1977. Stress-deformation and strength characteristics: state-of-the-art report. Proc. 9th Int. Conf. Soil Mech. and Foundation Eng., Tokyo, 2:421-494.
Lee, H.J., and Edwards, B.D., 1986. Regional method to assess offshore slope stability. J. Geotech. Div., Am. Soc. Civ. Eng., 112:489-509.

Lewis, K.B., 1971. Slumping on a continental slope inclined at 1-4 ${ }^{\circ}$. Sedimentology, 16:97-110.

Marine Geotechnical Consortium, 1985. Geotechnical properties of northwest Pacific pelagic clays: Deep Sea Drilling Project Leg 86, Hole 576 A. In Heath, G.R., Burckle, L.H., et al., Init. Repts. DSDP, 86: Washington (U.S. Govt. Printing Office), 723-758.

Masson, D.G., Kidd, R.B., Gardner, J.V., Huggett, Q.J., and Weaver, P.P.E., 1992. Saharan continental rise: facies distribution and sediment slides. In Poag, C.W., and de Graciansky, P.C. (Eds.), Geologic Evolution of Atlantic Continental Rises: New York (Van Nostrand Reinhold), 327-343.

Mayne, P.W., 1985. Stress anisotropy effects on clay strength. J. Geotech. Div., Am. Soc. Civ. Eng., 111:356-366.

Moore, D.G., 1961. Submarine slumps. J. Sediment. Petrol., 31:343-357.

Morgenstern, N.R., 1967. Submarine slumping and the initiation of turbidity currents. In Richards, A.F. (Ed.), Marine Geotechnology: Urbana (Univ. Illinois Press), 189-220.

Pittenger, A., Taylor, E., and Bryant, W.R., 1989. The influence of biogenic silica on the geotechnical stratigraphy of the Vøring Plateau, Norwegian Sea. In Eldholm, O., Thiede, J., Taylor, E., et al., Proc. ODP, Sci. Results, 104: College Station, TX (Ocean Drilling Program), 923-940.

Poulos, S.J., 1981. The steady state of deformation. J. Geotech. Div., Am. Soc. Civ. Eng., 107:553-562.

Roberts, J.A., 1994. A comparative investigation of submarine slope stability [Ph.D. thesis]. Univ. of Wales, Cardiff.

Roscoe, K.H., Schofield, A.N., and Wroth, C.P., 1958. On the yielding of soils. Geotechnique, 8:22-53.

Schofield, A.N., and Wroth, C.P., 1968. Critical State Soil Mechanics: London (McGraw-Hill).

Schwab, W.C., and Lee, H.J., 1983. Geotechnical analysis of submarine landslides in glacial marine sediment, northeast Gulf of Alaska. In Molnia, B.F. (Ed.), Glacial Marine Sedimentation: New York (Plenum), 145-184. , 1988. Causes of two slope-failure types in continental shelf sediment, northeastern Gulf of Alaska. J. Sediment. Petrol., 58:1-11.

Searle, R.C., Schultheiss, P.J., Weaver, P.P.E., Noel, M., Kidd, R.B., Jacobs, C.L., and Huggett, Q.J., 1985. Great Meteor East (Distal Madeira Abyssal Plain): Geological Studies of Its Suitability for Disposal of Heat-emitting Radioactive Wastes. Institute of Oceanographic Sciences, Rept. 193.

Shipboard Scientific Party, 1993. Site 883. In Rea, D.K., Basov, I.A., Janecek, T.R., Palmer-Julson, A., et al., Proc. ODP, Init. Repts., 145: College Station, TX (Ocean Drilling Program), 121-208.

Skempton, A.W., 1954. The pore pressure coefficients A and B. Geotechnique, 4:4-143.

, 1970. The consolidation of clays by gravitational compaction. $Q$. J. Geol. Soc. London, 125:373-411.

Taylor, D.W., 1948. Fundamentals of Soil Mechanics: New York (Wiley).

Whitman, R.V., 1985. On liquefaction. Proc. 11th Int. Conf. Soil Mech. and Foundation Eng., 4:1923-1926.

- Abbreviations for names of organizations and publications in ODP reference lists follow the style given in Chemical Abstracts Service Source Index (published by American Chemical Society).

Date of initial receipt: 6 April 1994

Date of acceptance: 10 August 1994

Ms 145SR-140 

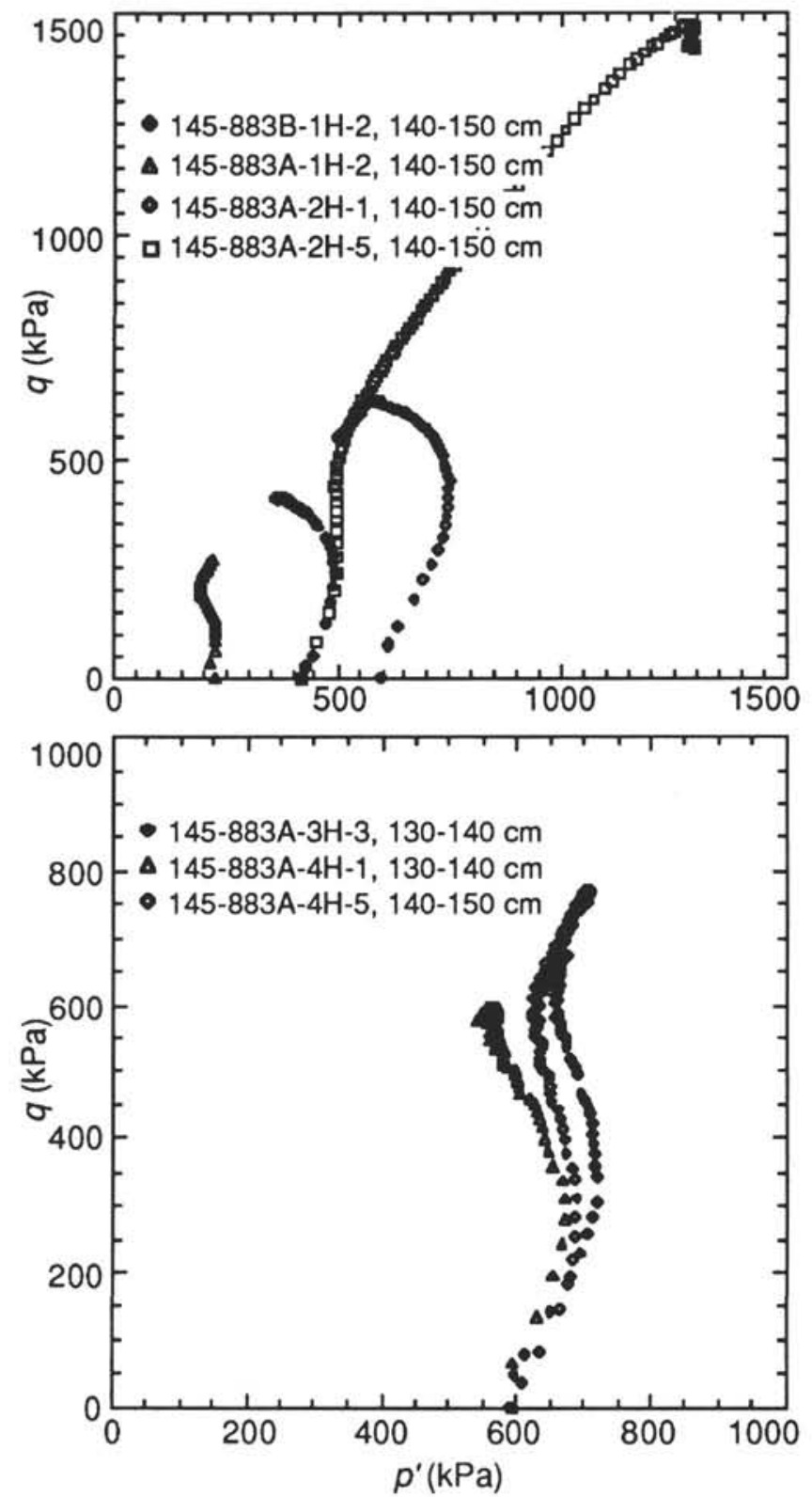

Figure 8. Effective stress path plots for the samples tested during this study. Two plots are used for clarity. Note different scales. 